Archives de sciences sociales des religions

136 | octobre - décembre 2006

Les Archives... cinquante ans après

\title{
Gerhard Robbers, éd., State and Church in the European Union
}

Baden-Baden, Nomos, 2005, 589 p.

Bérengère Massignon

\section{CpenEdition}

Édition électronique

URL : http://journals.openedition.org/assr/4037

DOI : 10.4000/assr.4037

ISSN : $1777-5825$

Éditeur

Éditions de l'EHESS

Édition imprimée

Date de publication : 1 décembre 2006

Pagination : 115-283

ISBN : 2-7132-2124-2

ISSN : 0335-5985

Référence électronique

Bérengère Massignon, " Gerhard Robbers, éd., State and Church in the European Union », Archives de sciences sociales des religions [En ligne], 136 | octobre - décembre 2006, document 136-94, mis en ligne le 14 février 2007, consulté le 21 septembre 2020. URL : http://journals.openedition.org/assr/4037 ;

DOI : https://doi.org/10.4000/assr.4037

Ce document a été généré automatiquement le 21 septembre 2020.

(c) Archives de sciences sociales des religions 


\section{Gerhard Robbers, éd., State and Church in the European Union}

Baden-Baden, Nomos, 2005, 589 p.

Bérengère Massignon

1 Cet ouvrage est une réédition comprenant, en plus d'un panorama réactualisé des relations Églises-États dans les quinze pays de l'Union, une présentation inédite des dix nouveaux entrants ; chaque rubrique est rédigée par un juriste du pays en question. Ce livre représente une somme d'informations précieuses, organisées en rubriques similaires, ce qui permet à la fois une lecture par pays et une approche comparative par thème.

2 Après une présentation, de la scène religieuse de chaque pays, assortie de chiffres, et un court rappel historique, les rubriques abordent les différentes facettes du droit des cultes : les principes directeurs contenus dans la Constitution et les grands textes législatifs, les différentes formes juridiques d'organisation des communautés religieuses, le droit à l'auto-organisation des communautés religieuses et les grandes caractéristiques $\mathrm{du}$ système des relations Églises/État. Suivent des rubriques thématiques abordant la place des religions dans l'éducation, les médias, le droit du travail ainsi que le financement des cultes, les aumôneries, le statut légal des clercs et le droit matrimonial. Une dernière section aborde la mention des religions dans le droit pénal (blasphème, sanction de l'appel à la haine religieuse, garantie de la liberté religieuse), question d'actualité si l'on considère la controverse autour de la publication des caricatures de Mahomet, au Danemark. Un dernier chapitre dresse une typologie des relations Églises-État en Europe, leurs points de convergence et les prémices d'un droit communautaire des religions, notamment les mentions des religions dans le Traité constitutionnel.

3 Ce livre offre un instantané du système des cultes de chaque pays, précis et documenté. On peut cependant regretter que la présentation ne soit pas plus dynamique et ne propose pas toujours, avec la même précision, les évolutions qui affectent le régime des cultes, au regard de la pluralisation grandissante de la scène religieuse européenne : par exemple l'ouverture du régime des congrégations à des religions non catholiques, 
en France ; les relations avec de nouvelles religions ou l'humanisme séculier, au niveau de certains Länder allemands, notamment en ce qui concerne l'expérimentation d'un cours de religion pour les musulmans et d'un enseignement comparatif des religions.

4 Pour plus de renseignements sur certains thèmes, sur l'actualité de la jurisprudence en droit des religions, ou sur les effets harmonisateurs de la jurisprudence de la Cour européenne des droits de l'Homme sur les législations européennes nationales, on pourra se reporter utilement à la publication de La revue européenne des relations ÉglisesÉtat ou aux actes des colloques annuels du Consortium européen pour les relations Églises-État, comprenant tous deux des rubriques par pays et un point sur la législation européenne transnationale. Ces différents ouvrages sont édités par le Consortium dont sont issus la plupart des auteurs de ce livre. 